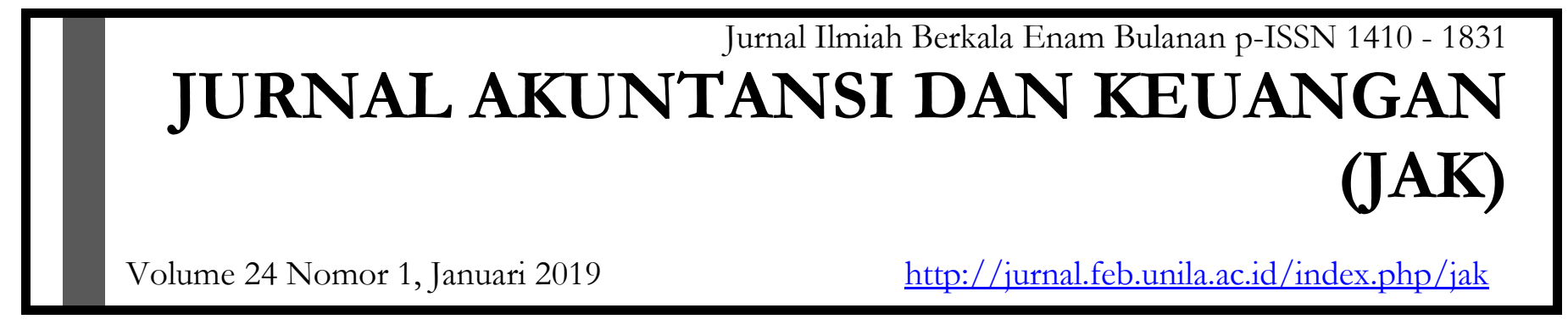

\title{
PENGARUH FINANCIAL DISTRESS, OPINI AUDIT, DAN PROFITABILITAS TERHADAP AUDIT REPORT LAG
}

\author{
Oftika Sari $^{1}$, Einde Evana ${ }^{2}$, Ninuk Dewi Kesumaningrum ${ }^{3}$ \\ 1 Jurusan Akuntansi Fakultas Ekonomi dan Bisnis Universitas Lampung \\ 2 Jurusan Akuntansi Fakultas Ekonomi dan Bisnis Universitas Lampung \\ 3 Jurusan Akuntansi Fakultas Ekonomi dan Bisnis Universitas Lampung
}

\section{Informasi Naskah}

Update Naskah:

Dikumpulkan:7 November 2018

Diterima: 14 Desember 2018

Terbit/Dicetak: 29 Januari 2019

\section{Keywords:}

audit report lag, financial

distress, opini audit, profitabilitas.

\section{$\underline{\text { Abstract }}$}

Penelitian ini bertujuan untuk menginvestigasi pengaruh financial distress, opini audit, dan profitabilitas terhadap audit report lag (studi empiris pada perusahaan perbankan dan perusahaan pembiayaan yang terdaftar di Bursa Efek Indonesia tahun 2012-2016). Metode yang digunakan dalam penelitian ini adalah kuantitatif dengan data sekunder dari Bursa Efek Indonesia, penelitian ini memiliki 53 perusahaan sampel dalam pemilihan berdasarkan teknik purposive sampling pada tahun 2012-2016. Analisis data menggunakan analisis regresi logistik dengan software SPSS 23. Hasil penelitian ini menunjukkan bahwa financial distress tidak berpengaruh terhadap audit report lag, opini audit berpengaruh negatif terhadap audit report lag, dan profitabilitas berpengaruh negatif terhadap audit report lag. Implikasi praktis dari penelitian ini sebagai pertimbangan bagi perusahaan dalam merencanakan pekerjaan lapangan dengan sebaik-baiknya sehingga dapat memperbaiki ketepatan pelaporan keuangan ataupun mempercepat publikasi laporan auditan. 


\section{A. PENDAHULUAN}

\section{Latar Belakang}

Laporan keuangan yang baik memiliki karakteristik kualitatif laporan keuangan. Menurut Ikatan Akuntan Indonesia (2017), terdapat empat karakteristik kualitatif pokok, yaitu dapat dipahami, relevan, keandalan, dan dapat diperbandingkan. Ketepatan waktu pelaporan keuangan termasuk dalam salah satu kualitas laporan keuangan yang memiliki peranan penting dalam pembuatan keputusan (Shukeri dan Nelson, 2011). Laporan keuangan perusahaan yang ditutup per tanggal 31 Desember tidak dapat selesai pada tanggal itu juga. Perusahaan masih memerlukan waktu untuk menyelesaikan laporan keuangan tersebut sampai dengan penyerahan kepada auditor untuk dilakukan audit. Lamanya waktu penyelesaian audit dapat mempengaruhi ketepatan waktu informasi tersebut dipublikasikan dan mempengaruhi manfaat informasi laporan keuangan. Rentang waktu dalam menyelesaikan pekerjaan audit hingga tanggal diterbitkannya laporan audit disebut Audit report lag (Juanita, 2012). Semakin panjang audit report lag, semakin lama auditor dalam menyelesaikan pekerjaan auditnya. Berdasarkan data per November 2017 terdapat 558 perusahaan yang terdaftar di Bursa Efek Indonesia, hal ini menunjukan bahwa terjadi penambahan jumlah perusahaan go public setiap tahunnya. Seiring dengan bertambahnya perusahaan yang terdaftar di BEI tersebut maka semakin banyak pula kebutuhan laporan audit atas laporan keuangan yang dihasilkan oleh perusahaan tersebut. Berdasarkan Keputusan Ketua BAPEPAMLK Nomor: KEP 431/BL/2012 tentang Penyampaian Laporan Tahunan Emiten atau Perusahan Publik yang menyatakan bahwa bagi setiap perusahaan publik yang terdaftar di Bursa Efek Indonesia (BEI) wajib menyampaikan laporan tahunan kepada BAPEPAM dan Lembaga Keuangan selambat-lambatnya 120 hari setelah tahun buku berakhir.

Lamanya audit report lag mempengaruhi nilai laporan keuangan yang telah diaudit. Karena keterlambatan penyampaian laporan keuangan yang telah diaudit mengindikasikan sinyal buruk dari perusahaan bagi pihak-pihak yang berkepentingan. Hal ini berimbas pada kenaikan atau penurunan harga saham perusahaan. Menurut Haryani dan Wiratmaja (2014) perusahaan yang mengalami audit report lag yang berkepanjangan akan merugikan beberapa pihak, bagi perusahaan audit report lag ini akan menghilangkan citra baik di mata investor perusahaan tersebut, sedangkan bagi investor terlambatnya publikasi laporan keuangan tersebut maka akan mempersulit mereka dalam mengambil keputusan terhadap laporan keuangan yang dihasilkan oleh perusahaan tersebut. Dengan demikian seorang auditor diharapkan dalam mengerjakan laporan auditnya selesai dengan tepat waktu agar pihakpihak yang menggunakan laporan keuangan tersebut tidak merasa dirugikan.

Berdasarkan data beberapa tahun terakhir, banyak emiten yang terdaftar di BEI tidak mampu tepat waktu dalam publikasi laporan keuangannya sebagaimana diperlihatkan pada tabel berikut: 
Tabel 1.1

Jumlah Perusahaan Go Public yang Terlambat Menyampaikan Laporan Keuangan

Periode 2012-2016

\begin{tabular}{|c|c|}
\hline Tahun Buku & Jumlah Perusahaan \\
\hline 2012 & 52 \\
\hline 2013 & 49 \\
\hline 2014 & 52 \\
\hline 2015 & 63 \\
\hline 2016 & 70 \\
\hline
\end{tabular}

Sumber: Data diolah (2018)

Tabel tersebut menjelaskan bahwa terdapat peningkatan jumlah perusahaan yang terlambat menyampaikan laporan keuangan tahunan seiring dengan bertambahnya jumlah perusahaan yang listing di Bursa Efek Indonesia, sedangkan berbagai regulasi telah diupayakan oleh BEI terkait sanksi bagi perusahaan yang melanggar aturan tersebut. Hal ini membuktikan perlunya penelitian mengenai penyebab keterlambatan pelaporan laporan keuangan. Audit report lag dipengaruhi oleh beberapa faktor diantaranya yaitu financial distress, opini audit, dan profitabilitas.

Banyak penelitian telah dilakukan terkait audit report lag, namun hasil dari beberapa penelitian tersebut masih beragam. Hal ini dikarenakan adanya perbedaan variabel independen yang diteliti, periode pengamatan, metode penelitian yang digunakan, dan sektor perusahaan yang diteliti. Sehingga ditinjau dari pentingnya informasi yang terkandung dalam laporan keuangan masih memberikan ruang untuk dikaji kembali. Sesuai dengan uraian perumusan masalah di atas, maka tujuan dari penelitian ini adalah untuk mengivestigasi apakah financial distress, opini audit, dan profitabilitas berpengaruh terhadap audit report lag.

Penelitian ini diharapkan dapat menambah studi literatur mengenai faktor-faktor yang berpengaruh terhadap audit report lag, memberikan landasan bagi penelitian selanjutnya yang sama di masa yang akan datang dimana bukti empiris tersebut dapat dijadikan tambahan wawasan dalam penelitian berikutnya, memberikan pemahaman atau gambaran tentang lamanya audit report lag pada sektor keuangan khususnya perusahaan perbankan dan perusahaan pembiayaan yang terdaftar di BEI, serta memberikan informasi agar mampu merencanakan pekerjaan lapangan dengan sebaik-baiknya sehingga dapat memperbaiki ketepatan pelaporan keuangan ataupun mempercepat publikasi laporan auditan.

\section{B. LANDASAN TEORI DAN PENGEMBANGAN HIPOTESIS}

\section{Teori Keagenan}

Dalam proses audit, teori keagenan menjelaskan hubungan antara manajemen (principal) dengan auditor independen (agent) (Jensen dan Meckling, 1986). Di dalam hubungan keagenan terdapat suatu kontrak yang dalam hal ini satu orang atau lebih (manajemen atau principal) memerintah orang lain (auditor independen atau agent) untuk melakukan suatu jasa atas nama principal dan memberi masukan dalam pengambilan keputusan. Bahasan audit report lag berkaitan erat dengan teori keagenan di mana perusahaan dapat meminta auditor untuk memeriksa lebih lanjut mengenai kewajiban jangka panjang dan laba rugi perusahaan yang berperan penting dalam laporan keuangan. Pemeriksaan lebih lanjut ini memerlukan waktu lebih dan akan mempengaruhi audit report lag. 


\section{Signalling Theory}

Signalling theory menjelaskan tentang suatu pihak (agent) menyampaikan informasi tentang dirinya sendiri kepada pihak lain (Connelly, 2012). Informasi ini merupakan sebuah sinyal. Sinyal yang dimaksud adalah tindakan yang diambil oleh manajemen perusahaan dimana manajemen mengetahui informasi yang lebih lengkap dan akurat mengenai internal perusahaan dan prospek perusahaan di masa depan daripada pihak investor. Manajer berkewajiban memberikan sinyal mengenai kondisi perusahaan kepada para stakeholder, yang dapat dilakukan melalui pengungkapan informasi akuntansi seperti publikasi laporan keuangan. Umumnya pasar akan merespon informasi tersebut sebagai suatu sinyal good news atau bad news. Sinyal yang diberikan akan mempengaruhi pasar saham khususnya harga saham perusahaan. Jika sinyal manajemen mengindikasikan good news, maka dapat meningkatkan harga saham. Namun sebaliknya, jika sinyal manajemen mengindikasikan bad news dapat mengakibatkan penurunan harga saham perusahaan. Oleh karena itu, sinyal dari perusahaan merupakan hal yang penting bagi investor guna pengambilan keputusan.

\section{Audit Report Lag}

Audit report lag adalah rentang waktu dalam menyelesaikan pekerjaan audit hingga tanggal diterbitkannya laporan audit (Juanita, 2012). Tanggal laporan auditan harus sama dengan tanggal selesainya pekerjaan lapangan karena menunjukkan batas tanggung jawab auditor untuk menjelaskan hal-hal penting yang terjadi (Agoes, 2012). Rata-rata lamanya audit report lag berbeda-beda di setiap negara tergantung dengan peraturan yang berlaku. Lamanya audit report lag disebabkan oleh auditor yang harus menemukan bukti-bukti audit serta mengkonsultasikannya dengan auditor senior dan menegosiasikannya dengan pihak manajemen.

\section{Financial Distress}

Menurut Plat dan Plat (dalam Endri, 2009), kesulitan keuangan (financial distress) adalah tahap penurunan kondisi keuangan yang terjadi sebelum perusahaan dinyatakan bangkrut. Pengertian tersebut menjelaskan bahwa kondisi kesulitan keuangan atau sering disebut sebagai financial distress adalah kondisi di mana perusahaan mengalami keuntungan bersih yang negatif. Dalam artian ini, laporan keuangan perusahaan membukukan rugi dalam nilai buku perusahaan. Kesulitan keuangan (financial distress) merupakan salah satu berita buruk dalam laporan keuangan yang merupakan tahap penurunan kondisi keuangan perusahaan dan apabila hal ini dibiarkan berlarut-larut maka akan menyebabkan perusahaan mengalami kebangkrutan. Perusahaan yang mengalami keadaan financial distress memiliki penyebab yang berbeda dari satu situasi ke situasi yang lain, penyebab suatu perusahaan mengalami kesulitan keuangan disebabkan melalui faktor internal maupun eksternal.

\section{Opini Audit}

Opini audit merupakan kesimpulan yang didapat dari proses audit yang dilakukan dalam bentuk pendapat mengenai laporan keuangan. Pendapat auditor biasanya disampaikan dalam bentuk tertulis yang umumnya berupa laporan audit. Pendapat auditor sangatlah penting bagi perusahaan ataupun pihak-pihak lain yang membutuhkan hasil dari laporan keuangan auditan karena laporan auditor dapat menambah kredibilitas laporan keuangan. 


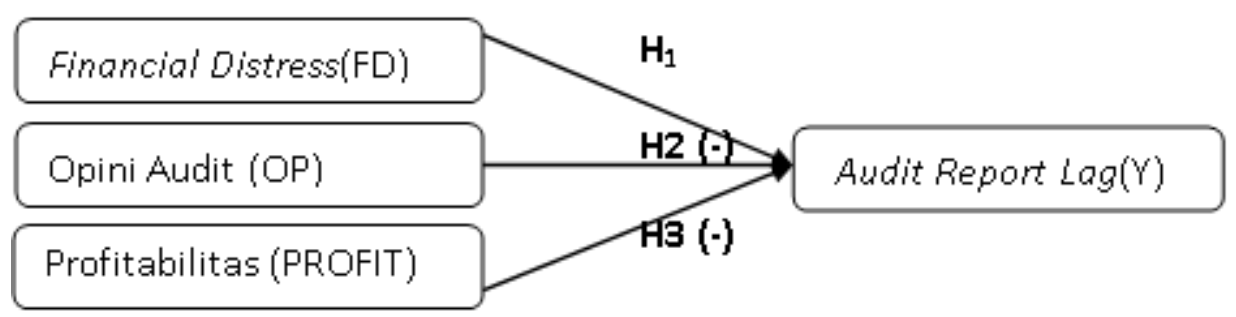

Gambar 2.1 Kerangka Pemikiran

\section{Pengembangan Hipotesis}

\section{Hubungan Financial Distress Terhadap Audit Report Lag}

Financial distress adalah suatu konsep luas yang terdiri dari beberapa situasi dimana suatu perusahaan menghadapi masalah kesulitan keuangan berupa kebangkrutan, kegagalan, ketidakmampuan melunasi hutang, dan default (Muniroh dan Suharsono, 2016). Berdasarkan penelitian Praptika dan Rasmini (2016) semakin tinggi nilai rasio financial distress maka perusahaan tersebut dianggap sedang mengalami kesulitan keuangan dan akan menambah lamanya waktu penyelesaian audit. Pihak manajemen akan berusaha mengurangi berita buruk ini sehingga akan memakan waktu lebih banyak.

Kondisi financial distress yang terjadi pada perusahaan dapat meningkatkan risiko audit pada auditor independen khususnya risiko pengendalian dan risiko deteksi. Dengan meningkatnya risiko itu maka auditor harus melakukan pemeriksaan risiko (risk assessment) sebelum menjalankan proses audit, tepatnya pada fase perencanaan audit (audit planning). Sehingga hal ini dapat mengakibatkan lamanya proses audit dan berdampak pada bertambahnya audit report lag. Berdasarkan uraian tersebut, maka dapat dirumuskan hipotesis sebagai berikut:

\section{H1: Financial distress berpengaruh pada audit report lag.}

\section{Hubungan Opini Audit Terhadap Audit Report Lag}

Pemberian unqualified opinion merupakan good news yang membuat calon investor tertarik melakukan investasi sehingga perusahaan akan lebih cepat dalam menyampaikan laporan keuangannya dan cenderung audit report lag yang lebih pendek (Parwati dan Suhardjo, 2009). Pada perusahaan yang menerima opini selain unqualified opinion akan terjadi negoisasi antara auditor dengan perusahaan tersebut, selain itu auditor juga perlu berkonsultasi dengan auditor yang lebih senior atau staf lain untuk semakin meyakinkan opininya akibatnya audit report lag akan relatif lebih lama (Iskandar dan Trisnawati, 2010).

Menurut Aditya dan Anisykurlillah (2014) arah hubungan yang ditimbulkan antara opini audit terhadap audit report lag adalah negatif, karena apabila perusahaan mendapat opini unqualified (wajar tanpa pengecualian) maka audit report lag akan berkurang daripada perusahaan yang mendapatkan opini selain unqualified. Hal ini sejalan dengan penelitian Prabowo dan Marsono (2013). Perusahaan yang hasil laporan auditnya mendapatkan opini unqualified opinion tentu saja ingin agar hasil opini tersebut segera diketahui oleh publik. Perusahaan yang mendapatkan opini selain unqulified opinion tentunya memerlukan waktu untuk berdiskusi kembali dengan auditor dan hal ini akan memperpanjang audit report lag. Berdasarkan uraian tersebut, maka dapat dirumuskan hipotesis sebagai berikut:

\section{H2 : Opini audit berpengaruh negatif terhadap audit report lag.}




\section{Hubungan Profitabilitas Terhadap Audit Report Lag}

Menurut Anastasia (2007) profitabilitas didefinisikan sebagai suatu kemampuan perusahaan menghasilkan laba dari kegiatan operasinya dan sering digunakan untuk mengukur kinerja perusahaan. Oleh karena itu sangat diperlukan ketepatwaktuan penyerahan laporan keuangan hasil audit sebagai alat untuk menaksir kinerja perusahaan. Semakin besar keuntungan yang diperoleh perusahaan maka semakin singkat audit report lag, sebab perusahaan ingin menyampaikan good news tersebut kepada pemegang sahamnya. Hal ini sejalan dengan penelitian Rachmawati (2008) yang menunjukkan profitabilitas berpengaruh terhadap audit report lag. Tinggi rendahnya profitabilitas mempengaruhi lama atau cepatnya penyampaian laporan keuangan seperti penelitian yang telah dilakukan oleh Rachmawati (2008), yang menyatakan bahwa profibilitas berpengaruh terhadap audit report lag. Sejalan dengan hasil penelitian yang dilakukan Lianto dan Kusuma (2012) menunjukkan bahwa adanya pengaruh negatif antara profitabilitas dengan audit report lag. Penelitian Parwati dan Suhardjo (2009) juga menunjukkan bahwa profitabilitas berpengaruh terhadap audit report lag. Berdasarkan uraian tersebut maka hipotesis dalam penelitian ini adalah sebagai berikut.

\section{H3: Profitabilitas berpengaruh negatif terhadap audit report lag.}

\section{METODOLOGI PENELITIAN}

\section{Populasi dan Sampel}

Populasi yang digunakan dalam penelitian ini adalah perusahaan sektor perbankan dan sektor pembiayaan yang terdaftar di Bursa Efek Indonesia (BEI) pada tahun 2012-2016. Pemilihan sampel menggunakan purposive sampling yang dipilih berdasarkan kriteria-kriteria sebagai berikut:

1. Perusahaan perbankan dan perusahaan pembiayaan yang terdaftar di Bursa Efek Indonesia (BEI) tahun 2012-2016.

2. Perusahaan perbankan dan perusahaan pembiayaan yang mengunggah Laporan Tahunan dan/atau Laporan Keuangan ke dalam website BEI tahun 2012-2016.

3. Perusahaan perbankan dan perusahaan pembiayaan yang memiliki informasi yang dibutuhkan secara lengkap tahun 2012-2016.

\section{Jenis dan Sumber Data}

Jenis data dalam penelitian ini adalah data sekunder. Data yang digunakan dalam penelitian ini adalah laporan tahunan perusahaan (annual report) yang dipublikasikan melalui website Bursa Efek Indonesia (BEI): www.idx.co.id.

\section{Variabel Penelitian dan Definisi Operasional Variabel Dependen}

Variabel dependen dalam penelitian ini adalah audit report lag. Berdasarkan Keputusan Ketua BAPEPAM-LK Nomor: KEP 431/BL/2012 tentang Penyampaian Laporan Tahunan Emiten atau Perusahan Publik yang menyatakan bahwa bagi setiap perusahaan publik yang terdaftar di Bursa Efek Indonesia (BEI) wajib menyampaikan laporan tahunan kepada BAPEPAM dan Lembaga Keuangan selambat-lambatnya 4 (empat) bulan setelah tahun buku berakhir. Oleh karena itu apabila perusahaan mempublikasikan laporan keuangan lebih dari 120 hari maka perusahaan tersebut mengalami audit 
report lag. Variabel ini diukur dengan menggunakan variabel dummy, dimana kategori 1 untuk perusahaan yang mengalami audit report lag, sedangkan kategori 0 untuk perusahaan yang tidak mengalami audit report lag (Sianipar, 2010).

\section{Variabel Independen}

\section{Financial Distress}

Financial distress merupakan kondisi perusahaan yang sedang dalam keadaan kesulitan keuangan. Dalam penelitian ini variabel financial distress diproksikan dengan model Altman Z-Score yang dimodifikasi pada tahun 1995 sebagai berikut:

$$
Z=6,56 X 1+3,26 X 2+6,72 X 3+1,05 X 4
$$

Keterangan:

$\mathrm{Z}=$ financial distress index

$\mathrm{X} 1=$ working capital/total asset

$\mathrm{X} 2$ = retained earnings / total asset

$\mathrm{X} 3$ = earning before interest and taxes/total asset

$\mathrm{X} 4$ = book value of equity/book value of total liabilities

Klasifikasi perusahaan yang sehat dan bangkrut didasarkan pada nilai Z-score model Altman modifikasi yaitu:

a. Jika nilai $\mathrm{Z}<1,1$ maka termasuk perusahaan yang mengalami financial distress.

b. Jika nilai $1,1<\mathrm{Z}<2,6$ maka termasuk grey area (tidak dapat ditentukan apakah perusahaan sehat ataupun mengalami financial distress).

c. Jika nilai $Z>2,6$ maka termasuk perusahaan yang tidak mengalami financial distress.

\section{Opini Audit}

Opini audit merupakan pendapat yang diberikan auditor atas kewajaran laporan keuangan suatu perusahaan. Variabel ini diukur dengan variabel dummy. Jika perusahaan mendapat opini wajar tanpa pengecualian (unqualified opinion) maka diberi nilai 1, dan sebaliknya jika mendapat opini selain unqualified opinion diberi nilai 0 (Che-Ahmad dan Shamharir, 2008).

\section{Profitabilitas}

Profitabilitas menunjukkan keberhasilan perusahaan dalam memperoleh keuntungan. Indikator yang digunakan untuk mengetahui tingkat profitabilitas suatu perusahaan dalam penelitian ini adalah return on asset (ROA). ROA menunjukkan kemampuan perusahaan menghasilkan laba dari aktiva yang dipergunakan dalam kegiatan operasional perusahaan (Muhardi, 2011). ROA diformulasikan dengan rumus sebagai berikut:

$$
R O A=\frac{\text { Net Income }}{\text { Total Asset }}
$$

Sumber: Muhardi (2011) 


\section{Metode Analisis Data}

\section{Statistik Deskriptif}

Statistik deskriptif menunjukkan jumlah sampel, nilai minimum, nilai maksimum, nilai rata-rata, dan standar deviasi (Ghozali, 2016).

\section{Uji Hipotesis}

Alat analisis yang digunakan dalam penelitian ini adalah regresi logistik. Menurut Ghozali (2016) metode ini cocok digunakan untuk penalitian yang variabel dependennya bersifat kategorikal (nominal atau metrik). Regresi logistik digunakan untuk menguji apakah variabel financial distress, opini audit, dan profitabilitas berpengaruh terhadap audit report lag. Adapun rumus yang digunakan adalah sebagai berikut:

$$
\mathrm{Y}=\alpha+\beta_{1} \mathrm{FD}+\beta_{2} \mathrm{OP}+\beta_{3} \mathrm{PROFIT}+\mathrm{e}
$$

\section{Dimana :}

\begin{tabular}{|c|c|}
\hline Y & $=$ Audit Report Lag \\
\hline$\alpha$ & $=$ Konstanta \\
\hline FD & $=$ Financial Distress \\
\hline $\mathrm{OP}$ & $=$ Opini Audit \\
\hline PROFIT & $=$ Profitabilitas \\
\hline$\beta_{1}, \beta_{2}, \beta_{3}$ & $=$ Koefisien regresi \\
\hline e & $=$ error \\
\hline
\end{tabular}

Menurut Ghozali (2016) terdapat beberapa hal yang perlu diperhatikan dalam analisis pengujian dengan menggunakan regresi logistik, yaitu:

1. Menilai kelayakan model regresi perhatikan output dari Hosmer and Lemeshow. Jika profitabilitas $>0,05$ maka $\mathrm{H} 0$ diterima, sedangkan jika profitabilitas <0,05 maka $\mathrm{H} 0$ ditolak.

2. Menilai keseluruhan model (Overall model fit). Penurunan log likelihood menunujukan model regresi yang baik.

3. Uji Koefisien Determinasi dengan Cox and Snell's $R$ square.

4. Uji Matriks Klasifikasi.

5. Menguji koefisien regresi. Jika p-value (significant) > 5\%, maka hipotesis alternatif ditolak. Sebaliknya, jika $p$-value $<5 \%$, maka hipotesis alternatif diterima.

\section{HASIL DAN PEMBAHASAN}

\section{Statistik Deskriptif}

Berdasarkan hasil uji statistik deskriptif diperoleh sebanyak 233 data observasi yang berasal dari perkalian antara periode penelitian (5 tahun; dari tahun 2012 sampai dengan 2016). Hasil statistik deskriptif dari variabel-variabel penelitian adalah sebagai berikut: 
Tabel Hasil Uji Statistik Diskriptif

\begin{tabular}{|c|c|c|c|c|}
\hline Variabel (N = 233) & Minimum & Maximum & Mean & $\begin{array}{c}\text { Std. } \\
\text { Deviation }\end{array}$ \\
\hline Financial Distress & $-1,9$ & 81,8 & 3,226 & 8,6284 \\
\hline Opini Audit & 0 & 1 & 0,64 & 0,480 \\
\hline Profitabilitas & $-0,07580$ & 0,14490 & 0,0228215 & 0,02488324 \\
\hline Audit Report Lag & 0 & 1 & 0,16 & 0,370 \\
\hline
\end{tabular}

Sumber: Data olahan (2018)

Tabel Klasifikasi Nilai Z-score

\begin{tabular}{|c|l|c|}
\hline $\begin{array}{c}\text { Klasifikasi nilai } \\
\text { Z-score }\end{array}$ & Kategori & $\begin{array}{c}\text { Jumlah } \\
\text { Sampel }\end{array}$ \\
\hline $\mathrm{Z}<1,1$ & Mengalami financial distress & 36 \\
\hline $1,1<\mathrm{Z}<2,6$ & Grey Area & 150 \\
\hline $\mathrm{Z}>2,6$ & Tidak mengalami financial distress & 47 \\
\hline \multicolumn{2}{|c|}{ Total sampel } & 233 \\
\hline
\end{tabular}

Sumber: Data olahan (2018)

Tabel di atas menjelaskan klasifikasi perusahaan yang sehat dan bangkrut didasarkan pada nilai Z-score model Altman modifikasi. Dari total sampel yang berjumlah 233, sampel yang termasuk kategori financial distress dengan nilai Z- score $<1,1$ berjumlah 36, sampel yang termasuk kategori grey area dengan nilai $\mathrm{Z}$-score $1,1<\mathrm{Z}<2,6$ berjumlah 150 , dan sampel yang termasuk kategori tidak mengalami financial distress dengan nilai Z-score $>2,6$ berjumlah 47 .

\section{Hasil Uji Analisis Regresi Logistik}

\section{Hasil Uji Kelayakan Model Regresi (Goodness of Fit) \\ Tabel Uji Kelayakan Model}

\section{Hosmer and Lemeshow Test}

\begin{tabular}{|l|l|l|l|}
\hline Step & Chi-square & Df & Sig. \\
\hline 1 & 3,674 & 8 &, 885 \\
\hline
\end{tabular}

Berdasarkan penilaian kelayakan model regresi (Goodness of Fit) pada tabel diatas nilai signifikansi Hosmer and Lemeshow test menunjukan angka sebesar 0,885. Dengan demikian nilai tersebut lebih besar daripada tingkat signifikansi alpha 5\%. Hal ini menunjukan bahwa model dapat diterima atau layak dalam menjelaskan variabel penelitian.

\section{Hasil Uji Kesesuaian Keseluruhan Model (Overall Model Fit)}

Tabel Uji Kesesuaian Keseluruhan Model

\begin{tabular}{|c|c|}
\hline $\mathbf{- 2}$ Log Likehood & Iteration History \\
\hline Block 0 & 201,398 \\
\hline Block 1 & 195,343 \\
\hline & 6,055 \\
\hline
\end{tabular}

Sumber: Data olahan (2018) 
Berdasarkan tabel di atas nilai -2 Log Likehood awal adalah sebesar 201,398 dan nilai -2 Log Likehood akhir sebesar 195,343. Dari hasil tersebut dilihat bahwa nilai -2 Log Likehood mengalami penurunan sebesar 6,055. Artinya menunjukkan model regresi baik atau dengan kata lain model yang dihipotesiskan fit dengan data. Maka dapat disimpulkan bahwa model regresi logistik secara keseluruhan layak digunakan.

\section{Hasil Uji Koefisien Determinasi (Nagelkerke R. Square)}

\section{Tabel Uji Koefisien Determinasi}

\begin{tabular}{|c|c|c|c|}
\hline Step & $\begin{array}{c}-2 \text { Log } \\
\text { likelihood }\end{array}$ & $\begin{array}{c}\text { Cox \& Snell } \\
\text { R Square }\end{array}$ & $\begin{array}{c}\text { Nagelkerke } R \\
\text { Square }\end{array}$ \\
\hline 1 & $195,343^{\mathrm{a}}$ &, 050 &, 085 \\
\hline
\end{tabular}

Sumber: Data diolah menggunakan SPSS 23

Berdasarkan tabel nilai Nagelkerke $R$ Square sebesar 0,085 yang berarti variabilitas variabel dependen yang dapat dijelaskan oleh variabilitas variabel independen adalah sebesar $8,5 \%$ dan sisanya sebesar 91,5\% dijelaskan oleh variabel-variabel lain di luar model penelitian.

\section{Hasil Matriks Klasifikasi}

Tabel Hasil Matriks Klasifikasi

\begin{tabular}{|c|c|c|c|}
\hline Observed & $\begin{array}{c}\text { Tidak Mengalami } \\
\text { Audit Report Lag }\end{array}$ & $\begin{array}{c}\text { Mengalami Audit } \\
\text { Report Lag }\end{array}$ & $\begin{array}{c}\text { Percentage } \\
\text { Correct }\end{array}$ \\
\hline $\begin{array}{c}\text { Tidak Mengalami } \\
\text { Audit Report Lag }\end{array}$ & 193 & 2 & 99,0 \\
\hline $\begin{array}{c}\text { Mengalami Audit } \\
\text { Report Lag }\end{array}$ & 36 & 2 & 5,3 \\
\hline \multicolumn{2}{|r|}{ Overall Percentage } & 83,7 \\
\hline
\end{tabular}

Sumber: Data olahan (2018)

Berdasarkan hasil uji matrik klasifikasi menunjukkan bahwa perusahaan perbankan dan perusahaan pembiayaan yang tidak mengalami audit report lag adalah 195 perusahaan, sedangkan hasil observasinya adalah 193 perusahaan jadi ketepatan klasifikasi 99\%. Sedangkan perusahaan yang mengalami audit report lag terdapat 38 perusahaan dan hasil observasi hanya 2 perusahaan jadi ketepatan klasifikasi 5,3\%. Nilai overall percentage adalah $83,7 \%$ yang berarti ketepatan model penelitian ini adalah sebesar $83,7 \%$.

\section{Interpretasi Hasil Penelitian dan Pembahasan}

\section{Pengujian Hipotesis}

Tabel Hasil Uji Hipotesis

\begin{tabular}{|l|c|c|}
\hline \multicolumn{1}{|c|}{ Variabel } & B & Sig. \\
\hline Financial Distress & 0,020 & 0,282 \\
\hline Opini Audit & $-0,755$ & 0,041 \\
\hline Profitabilitas & $-20,313$ & 0,021 \\
\hline
\end{tabular}

Sumber: Data olahan (2018) 
Berdasarkan hasil uji hipotesis pada tabel dua dari tiga variabel independen memiliki uji signifikansi < 0,05 yaitu opini audit sebesar 0,041 dan profitabilitas sebesar 0,021. Penjelasan mengenai variabel independen terhadap variabel dependen sebagai berikut:

1. Variabel financial distress (FD) menunjukkan koefisiensi regresi positif sebesar 0,020 dengan tingkat signifikansi (p) sebesar 0,282 (lebih besar dari $\alpha=5 \%$ ). Karena tingkat signifikansi (p) lebih besar dari $\alpha=5 \%$ maka hipotesis pertama (H1) dari penelitian ini yang menyatakan bahwa financial distress berpengaruh pada audit report lag tidak terdukung. Hasil penelitian ini membuktikan bahwa financial distress tidak berpengaruh terhadap audit report lag.

2. Variabel opini auditor (OP) menunjukkan koefisiensi regresi negatif sebesar -0,755 dengan tingkat signifikansi (p) sebesar 0,041 (lebih kecil dari $\alpha=5 \%$ ). Karena tingkat signifikansi (p) lebih kecil dari $\alpha=5 \%$ maka hipotesis kedua (H2) dari penelitian ini yang menyatakan bahwa opini audit berpengaruh negatif terhadap audit report lag terdukung. Hasil penelitian ini membuktikan bahwa opini audit berpengaruh negatif terhadap audit report lag.

3. Variabel profitabilitas (PROFIT) menunjukkan koefisiensi regresi negatif sebesar -20,313 dengan tingkat signifikansi (p) sebesar 0,021 (lebih kecil dari $\alpha=5 \%$ ). Karena tingkat signifikansi (p) lebih kecil dari $\alpha=5 \%$ maka hipotesis ketiga (H3) dari penelitian ini yang menyatakan bahwa profitabilitas berpengaruh negatif terhadap audit report lag terdukung. Hasil penelitian ini membuktikan bahwa profitabilitas berpengaruh negatif terhadap audit report lag.

\section{Pembahasan Hasil Penelitian}

\section{Pengaruh Financial Distress Terhadap Audit Report Lag}

Berdasarkan hasil pengujian statistik hipotesis membuktikan bahwa financial distress tidak berpengaruh signifikan terhadap audit report lag. Hal ini disebabkan karena tidak semua perusahaan yang mengalami financial distress akan mengalami audit report lag, sebab auditor yang bekerja secara profesional akan bekerja sesuai jadwal penyelesaian laporan audit yang disepakati sebelumnya. Sehingga auditor dapat meminimalisir resiko audit yang akan mempengaruhi audit report lag. Hal ini sejalan dengan penelitian yang telah dilakukan oleh Budiasih dan Saputri (2014) yang menyatakan bahwa financial distress tidak berpengaruh terhadap audit report lag. Namun bertentangan dengan penelitian yang dilakukan oleh Praptika dan Rasmini (2016) financial distress berpengaruh positif pada audit report lag.

\section{Pengaruh Opini Audit Terhadap Audit Report Lag}

Berdasarkan hasil pengujian opini audit berpengaruh negatif signifikan terhadap audit report lag. Perusahaan yang hasil laporan auditnya mendapatkan opini unqualified opinion tentu saja ingin agar hasil opini tersebut segera diketahui oleh publik sehingga audit report lag semakin singkat karena tidak perlu negosiasi dengan klien dan auditor senior. Pemberian unqualified opinion merupakan good news yang membuat calon investor tertarik melakukan investasi sehingga perusahaan akan lebih cepat dalam menyampaikan laporan keuangannya dan cenderung audit report lag yang lebih pendek (Parwati dan Suhardjo, 2009). Hal ini sejalan dengan penelitian yang telah dilakukan oleh Aditya dan Anisykurlillah (2014) serta Prabowo dan Marsono (2013) yang menyatakan bahwa opini auditor ini 
berpengaruh negatif terhadap audit report lag. Namun bertentangan dengan penelitian yang dilakukan oleh Tiono dan Jogi (2013) serta Trianto, et al. (2014) yang menyatakan bahwa opini audit tidak berpengaruh terhadap audit report lag.

\section{Pengaruh Profitabilitas Terhadap Audit Report Lag}

Berdasarkan hasil pengujian membuktikan bahwa variabel profitabilitas berpengaruh negatif signifikan terhadap audit report lag. Profitabilitas yang tinggi menggambarkan kinerja manajemen yang baik. Hal ini akan mempengaruhi cepat atau lambatnya manajemen melaporkan kinerjanya. Kinerja baik merupakan berita baik bagi reputasi perusahaan di mata publik, maka manajemen akan segera melaporkan berita baik itu. Semakin besar keuntungan yang diperoleh perusahaan maka semakin singkat audit report lag, sebab perusahaan ingin menyampaikan good news tersebut kepada pemegang sahamnya. Hal ini sejalan dengan penelitian Rachmawati (2008) yang menunjukkan profitabilitas berpengaruh terhadap audit report lag. Tinggi rendahnya profitabilitas mempengaruhi lama atau cepatnya penyampaian laporan keuangan. Penelitian yang telah dilakukan oleh Lianto dan Kusuma (2012) serta Parwati dan Suhardjo (2009) juga menunjukkan bahwa profitabilitas berpengaruh negatif terhadap audit report lag. Namun bertentangan dengan penelitian yang dilakukan oleh Azhari (2014) serta Tiono dan Jogi (2013) yang menyatakan bahwa profitabilitas tidak berpengaruh terhadap audit report lag.

\section{E. SIMPULAN DAN SARAN}

\section{Simpulan}

Berdasarkan hasil pengolahan data yang telah dilakukan, diperoleh kesimpulan sebagai berikut:

1. Financial distress tidak memiliki pengaruh terhadap audit report lag. Hal ini dikarenakan auditor yang bekerja secara profesional akan bekerja sesuai jadwal rencana penyelesaian laporan audit yang telah ditentukan sebelumnya.

2. Opini audit berpengaruh negatif terhadap audit report lag. Perusahaan yang hasil laporan auditnya mendapatkan opini unqualified opinion tentu saja ingin agar hasil opini tersebut segera diketahui oleh publik sehingga audit report lag semakin singkat karena tidak perlu negosiasi dengan klien dan auditor senior.

3. Profitabilitas berpengaruh negatif terhadap audit report lag. Semakin besar keuntungan yang diperoleh perusahaan maka semakin singkat audit report lag, sebab perusahaan ingin menyampaikan good news tersebut kepada pemegang sahamnya.

\section{Saran}

Disarankan untuk penelitian selanjutnya agar dapat memperluas sampel dari sektor lain seperti manufaktur, pertambangan, dan sektor lainnya atau dengan menggunakan sampel dari semua jenis sektor yang ada sehingga mempu mencerminkan keseluruhan populasi atas audit report lag. Serta memperluas penelitian dengan cara memperpanjang periode penelitian dengan menambahkan tahun penelitian, juga memperbanyak sampel untuk penelitian yang akan datang. 


\section{REFERENSI}

Aditya, Alifian Nur dan Indah Anisykurlillah. 2014. Faktor-Faktor yang Berpengaruh Terhadap Audit Report Lag. Accounting Analysis Journal. 3(3): 334-342.

Agoes, Sukrisno. 2013. Auditing: Petunjuk Praktis Pemeriksaan oleh Akuntan Publik Edisi Keempat. Jakarta. Salemba Empat.

Anastasia, Thio. 2007. Analisis Skala Perusahaan, Profitabilitas, Opini Audit, Pos Luar Biasa, dan Umur Perusahaan atas Audit Delay. Akuntabilitas. 144- 156

Azhari, Muhammad. 2014. Faktor- Faktor yang Mempengarruhi Audit Delay (Studi Kasus pada Perusahaan Perbankan yang Terdaftar Di Bursa Efek Indonesia). Sekolah Tinggi Ilmu Ekonomi Indonesia (STIESIA) Surabaya. Jurnal Ilmu dan Riset Akuntansi. 3(10).

Bapepam-LK. 2012. Peraturan Bapepam X.K.6 (Lampiran Keputusan Ketua Bapepam Nomor Kep 431/BL/2012 tanggal 1 Agustus 2012). Penyampaian Laporan Tahunan Emiten atau

Perusahaan Publik. Jakarta. Badan Pengawas Pasar Modal dan Lembaga Keuangan.

Budiasih, I Gusti Ayu Nyoman dan P. Dwi Aprisia Saputri. 2014. Corporate Governance dan Financial Distress pada Kecepatan Publikasi Laporan Keuangan. KINERJA. 18(2): 157-167.

Che-Ahmad, Ayoib dan Abidin Shamharir. 2008. Audit Delay of Listed Companies: A Case of Malaysia. International Business Research. 1(4): 32- 39.

Connelly, Brian L. 2012. Signalling theory: A Review and Assessment. Journal Citation Reports. 37(1): 39-67.

Endri. 2009. Prediksi Kebangkrutan Bank Menghadapi dan Mengelola Perubahan Lingkungan Bisnis: Analisis Model Altman's Z-Score. Jakarta. ABFI Perbanas.

Ghozali, Imam. 2016. Aplikasi Analisis Multivariete dengan Program IBM SPSS 23. Cetakan VIII. Semarang. Badan Penerbit Universitas Diponegoro.

Halim, Varianada. 2010. Faktor-Faktor yang Mempengaruhi Audit Report Lag: Studi Empiris Perusahaan-Perusahaan di Bursa Efek Jakarta. Jurnal Bisnis dan Akuntansi. 2(1): 63-75.

Haryani, Jumratul dan I Wiratmaja. 2014. Pengaruh Ukuran Perusahaan, Komite Audit, Penerapan International Financial Reporting Standards dan Kepemilikan Publik pada Audit Report Lag. E-Jurnal Akuntansi Universitas Udayana. 6(1): 63-74.

Hilmi, Utari dan Syaiful Ali. 2008. Analisis Faktor-Faktor yang Mempengaruhi Ketepatan Waktu Penyampaian Pelaporan Keuangan (Studi Empiris pada Perusahaan-Perusahaan yang Terdaftar di BEJ). Simposium Nasional Akuntansi XI. Pontianak.

Ikatan Akuntan Indonesia. 2009. Standar Profesi Akuntan Publik. Jakarta. Salemba Empat.

Ikatan Akuntan Indonesia. 2017. Pernyataan Standar Akuntansi Keuangan (PSAK). Jakarta. Salemba Empat.

Iskandar, Meylisa Januar dan Estralita Trisnawati. 2010. Faktor-Faktor yang Mempengaruhi Audit Report Lag Pada Perusahaan yang Terdaftar di Bursa Efek Indonesia. Jurnal Bisnis dan Akuntansi. 12(3): 175-186.

Juanita, Greta. 2012. Pengaruh Ukuran Kantor Akuntan Publik, Kepemilikan, Laba Rugi, Profitabilitas dan Solvabilitas Terhadap Audit Report Lag. Jurnal Bisnis dan Akuntansi. 14(1): 31-40.

Kieso, D. E., Weygandt, J. J., dan Warfield, T. D. 1995. Akuntansi Intermediate. Binarupa Aksara. 
Jakarta. Erlangga.

Lianto, Novice dan Budi Hartono Kusuma. 2012. Faktor-Faktor yang Berpengaruh Terhadap Audit Report Lag. Jurnal Bisnis dan Akuntansi. 12(2): 97-106.

Listiana, Lisa dan Tri Pujadi Susilo. 2012. Faktor-faktor yang Mempengaruhi Reporting Lag Perusahaan..Media Riset Akuntansi. 2(1): 48-64.

Muhardi, Werner R. 2011. Analisis Laporan Keuangan. Surabaya. Salemba Empat.

Muniroh dan Agus Suharsono. 2016. Klasifikasi Dynamic Financial Distress Perusahaan Manufaktur yang Terdaftar di Bursa Efek Indonesia Tahun 2012- 2014 Menggunakan Regresi Logistik Biner dan Classification Analysis dan Regression Tree (CART). Jurnal Sains dan Seni ITS. 5(2).

Parwati, Lina Anggraeni dan Yohanes Suhardjo. 2009. Faktor-Faktor yang Mempengaruhi Audit Report Lag (ARL). SOLUSI. 8(3): 29-42.

Prabowo, Pebi Putra Tri dan Marsono. 2013. Faktor-Faktor yang Mempengaruhi Audit Report Lag. Diponegoro Journal of Accounting. 2(1): 1- 11.

Praptika, Putu Yulia Hartanti dan Ni Ketut Rasmini. 2016. Pengaruh Audit Tenure, Pergantian Auditor Dan Financial Distress Pada Audit Delay pada Perusahaan Consumer Goods. E-Jurnal Akuntansi Universitas Udayana. 15(3): 2052-2081.

Rachmawati, Sistya. 2008. Pengaruh Faktor Internal dan Eksternal Perusahaan Terhadap Audit Report Lag dan Timeliness. Jurnal Akuntansi dan Keuangan. 10(1): 1-10.

Raharjo, E. 2007. Teori Agensi dan Teori Stewardship dalam Perspektif Akuntansi. Dalam Fokus Ekonomi. 2(1): 37-46.

Shukeri, S. N. dan Nelson, S. P. 2011. Timeliness of Annual Audit Report: Some Empirical Evidence from Malaysia. Entrepreneurship and Management International Conference (EMIC) 2. Kangar, Perlis Malaysia.

Sianipar, Charles V. 2010. Analisis Faktor-faktor yang Mempengaruhi Audit Delay. Jurnal Akuntansi Fakultas Ekonomi Mpu Tantular. 10(1): 1-26.

Sugiyono. 2010. Metode Penelitian Bisnis. Bandung. CV Alfabeta.

Sumartini, Ni Komang Ari dan Ni Luh Sari Widhiyani. 2014. Pengaruh Opini Audit, Solvabilitas, Ukuran Kap dan Laba Rugi pada Audit Report Lag. E- Jurnal Akuntansi Universitas Udayana. 9(1): 392-409.

Tiono, Ivena dan Yulius Jogi. 2013. Faktor-Faktor yang Mempengaruhi Audit Report Lag di Bursa Efek Indonesia. BUSINESS ACCOUNTING REVIEW. 2(2): 286-297.

Trianto, Imam., R. Adri Satriawan dan Yuneita Anisma. 2014. Analisis Faktor-Faktor yang Mempengaruhi Audit Delay (Studi Empiris pada Perusahaan Pertambangan yang terdaftar di Bursa Efek Indonesia). Jom FEKON. 1(2).

www.idx.co.id diakses pada tanggal 27 November 2017 pukul 15.30 